\title{
HUBUNGAN ANTARA IL-6 ADENOID DAN TONSILA PALATINA DENGAN IL-6 SERUM PADA ADENOTONSILITIS KRONIS HIPERTROFI
}

\author{
Khuznita Dasa Novita*西, Edi Handoko** ${ }^{*}$ Dyah Indrasworo**
}

\begin{abstract}
Abstrak
Adanya inflamasi lokal persisten pada Adenotonsilitis Kronis Hipertrofi (ATKH) menyebabkan perubahan histomorfologi berupa hiperplasi dan hipertrofi limfoid yang berhubungan dengan proliferasi sel $T$ dan sel B. IL-6 berperan pada inflamasi kronis melalui rekrutmen monosit ke daerah inflamasi dan mengubah keseimbangan Th1/Th2 menuju dominasi Th2. Kadar IL-6 jaringan dan serum meningkat pada ATKH, namun hubungan kadar IL-6 pada adenoid dan tonsila palatina dengan kadar IL-6 serum belum diketahui. Tujuan penelitan ini adalah untuk mengetahui hubungan kadar IL-6 adenoid dan tonsila palatine dengan kadar IL-6 serum. Penelitan ini melibatkan 8 anak dengan kasus ATKH (rata-rata umur: 9,63 $\pm 3,23$ tahun dan 8 anak kontrol sehat (rata-rata umur: 10,6 \pm 3.02 tahun). Kadar IL-6 diperiksa dari serum, adenoid, dan tonsila palatina dengan metode ELISA. Data penelitian dianalisis dengan independent t-test, uji korelasi, dan regresi linear. Hasil penelitan ini kadar IL-6 serum kelompok kasus lebih tinggi secara bermakna dibandingkan dengan kontrol sehat $(p<0,05)$. Terdapat hubungan positf yang bermakna antara kadar IL-6 adenoid dengan serum $(r=0,881, p=0,004)$. Sedangkan antara kadar IL-6 tonsila palatina dengan serum menunjukkan adanya hubungan yang tidak bermakna $(r=0,556, p=0,197)$. Dapat disimpulkan bahwa kadar IL-6 pada adenoid berhubungan positip dengan kadar IL-6 serum.
\end{abstract}

Kata Kunci: adenoid, adenotonsilitis kronis hipertrofi, IL-6, tonsil

\section{CORRELATION BETWEEN IL-6 OF ADENOID AND PALATINE TONSIL WITH IL-6 SERUM LEVEL IN CHRONIC HYPERTROPHY ADENOTONSILITIS}

\begin{abstract}
The presence of persistent local inflammation in Chronic Hypertrophy Adenotonsilitis (CHAT) cause histomorfologi changes of lymphoid hyperplasia and hypertrophy which associated with $T$ and $B$ cells proliferation are played by IL-6. IL-6 plays a role in chronic inflammation through recruitment of monocytes to the inflammatory area and change the Th1/Th2 balance toward Th2 dominant IL-6 tissue and serum levels increased in CHAT, but the relationship between IL-6 adenoid and palatine tonsil with IL-6 serum levels are sill not known. The purpose of this study was to determine the relationship between IL-6 of adenoid and palatine tonsil with IL-6 serum levels. This study included 8 children as case group (mean of age: $9.6 \pm 3.23$ years old) and 8 children as control group (mean of age: $10.6 \pm 3.02$ years old). IL-6 levels from serum, adenoid gland and palatine tonsil were examined by ELISA method. The research data were analysed by independent $\mathrm{t}$-test, correlation and linear regression. The results showed that IL-6 serum levels in case group was significantly higher $(p<0.05)$ compared with control group. There was a significantly positive relationship between IL- 6 of adenoid and serum levels $(r=0.881, p=0.004)$. Meanwhile, IL- 6 palatine tonsil and serum levels showed no significantly correlation $(r=0.556, p=0.197)$. It can be concluded that the level of IL-6 adenoid is associated with IL-6 serum levels.
\end{abstract}

Keywords: adenoid, chronic hypertrophy adenotonsilitis, IL-6, tonsil

\footnotetext{
*Departemen Anatomi Histologi, Fakultas Kedokteran UB

"Departemen IImu Kesehatan THT-KL Fakultas Kedokteran Universitas Brawijaya - RSUD Dr. Saiful Anwar Malang
}

\footnotetext{
Email: khuznita.fkub@gmail.com
} 


\section{Pendahuluan}

Adenoid dan tonsila palatina merupakan kelenjar limfe sekunder pembentuk komponen terbesar Waldeyer's ring dan termasuk bagian dari sistem Mucosa Associated Lymphoid Tissue (MALT). Jaringan limfe ini terletak di jalan masuk saluran pernafasan atas dan pencernaan. Karena itu, tonsil merupakan pertahanan yang pertama pada saluran pernafasan dan pencernaan. ${ }^{1}$ Adenoid dan tonsila palatina tidak memiliki saluran limfe aferen sehingga pembuluh darah merupakan satu-satunya jalan masuk limfosit menuju adenoid dan tonsila palatina. Pembuluh darah ini disebut High Endothelial Venule (HEV). HEV adalah venula postkapiler khusus yang dilapisi oleh epitel kuboid atau high endothelial cells. ${ }^{2}$ Sistem pertahanan tonsil diawali dengan kripte tonsil yang berfungsi menangkap berbagai macam antigen dan mempresentasikannya ke limfosit. Sel-sel yang berperan adalah sel dendrit, sel mukosa (sel M), dan follicular dendritic cell (FDC). Komponen sel di dalam kripte akan berubah seiring dengan makin seringnya terjadi infeksi. Berdasarkan penelitian yang dilakukan oleh Passali, terdapat perubahan epitel dan folikel berupa hiperplasi dan peningkatan sel T dan sel B. ${ }^{3}$

IL-6 adalah sitokin pleiotropik yang memiliki aktifitas biologik yang luas. Sifat pleiotropik dan kekayaan aktifitas fungsi IL-6 disebabkan oleh sistem reseptornya yang unik yaitu IL-6R dan transduser sinyal umum yaitu gp130. Hanya beberapa sel yang mengekspresikan IL-6R, yaitu hepatosit, neutrofil, monosit, sel $B$, dan sel $T$. Sel endotel tidak mengekspresikan IL-6R, tetapi di dalam serum terdapat reseptor IL-6 yang terlarut (slL-6R) sehingga dapat berikatan dengan IL-6 melalui mekanisme transsignalling. ${ }^{4} \mathrm{IL}-6$ berperan pada infeksi akut maupun kronis, hematopoesis, pembentukan sel T dan sel B. ${ }^{5}$
Penelitian tentang sitokin-sitokin yang berhubungan dengan adenotonsilitis kronis telah banyak dilakukan baik di serum maupun jaringan. Terdapat peningkatan kadar IL-6 baik di serum maupun di adenoid dan tonsila palatina pada adenotonsilitis kronis. $6,7,8$ Peradangan kronis ditandai oleh rekrutmen monosit ke daerah peradangan yang diperankan oleh IL-6. Komplek IL-6 dan slL$6 \mathrm{R} \alpha$ yang berikatan dengan gp130 melalui mekanisme trans-signaling dapat mengaktifkan sel endotel untuk menghasilkan IL-8, MCP-1, menginduksi ekspresi molekul adhesi, dan peningkatan IL- 6 itu sendiri. Hal inilah yang dapat meningkatkan kadar IL-6 serum. ${ }^{9}$ Dengan demikian, IL-6 merupakan dasar patofisiologi terjadinya adenoid hipertrofi. Penelitian yang menghubungkan antara kadar IL-6 serum dengan kadar IL-6 adenoid dan tonsila palatina belum dilakukan. Apabila terdapat hubungan antara kadar IL-6 adenoid dan tonsila palatina dengan kadar IL6 serum maka evaluasi terapi dapat dilakukan melalui pemeriksaan IL-6 serum.

\section{Bahan dan Metode}

Penelitian dilakukan dengan desain case control untuk mengetahui perbedaan kadar IL-6 serum pada anak dengan adenotonsilitis kronis hipertrofi (kasus) dan tanpa adenotonsilitis kronis hipertrofi (kontrol). Penelitian dilanjutkan dengan desain cross sectional untuk mengetahui hubungan kadar IL- 6 adenoid dan tonsila palatina terhadap IL-6 serum pada penderita adenotonsiltis kronis hipertrofi. Penelitian ini dilakukan di RSUD Dr. Saiful Anwar Malang mulai Desember 2012 sampai Mei 2013 pada 8 anak kasus dan 8 anak kontrol yang memenuhi kriteria penerimaan dan penolakan. Pengambilan sampel pada penelitian ini dilakukan dengan teknik consecutive sampling. Kriteria inklusi kelompok kasus adalah anak umur 5-14 tahun, didiagnosis sebagai adenotonsilitis 
kronis hipertrofi, bersedia dilakukan adenotonsilektomi dengan bius umum dan ikut dalam penelitian dengan persetujuan orang tua. Pengukuran adenoid berdasarkan metode Fujioka ${ }^{10}$, dan tonsila palatina berdasarkan Lopez-Gonzalez ${ }^{11}$. Kriteria inklusi kelompok kontrol adalah anak umur 5 14 tahun, dinyatakan tanpa adenotonsilitis kronis hipertrofi, dan bersedia ikut dalam penelitian dengan persetujuan orang tua. Kriteria penolakan kelompok kasus dan kelompok kontrol adalah bila terdapat tumor ganas atau jinak berdasarkan anamnesa dan pemeriksaan fisik, dan sedang mengalami radang akut berdasarkan pemeriksaan laboratorium. Berdasarkan Surat Keterangan Kelaikan Etik No: 367/KEPK/XI/2012, penelitian ini telah disetujui oleh Komite Etik Penelitian RSSAMalang.

Diagnosis adenotonsilitis kronis hipertrofi ditegakkan berdasarkan anamnesa, pemeriksaan fisik, dan foto polos skull lateral soft tissue. Pada anamnesa didapatkan sering terdapat sumbatan hidung, suara sengau, bernapas melalui mulut, mendengkur, terbangun malam hari karena gelagapan, sakitmenelan, rasa mengganjal di tenggorok dengan insiden 7 kali dalam 1 tahun atau 5 kali per tahun dalam 2 tahun berturut-turut atau 3 kali pertahun dalam 3 tahun berturut-turut. Pada pemeriksaan fisik didapatkan ukuran tonsila palatina $\geq+3$ dan tidak terdapat tanda radang akut lokal, pada pemeriksaan foto polos skull lateral soft tissue didapatkan $\mathrm{AN}>0,52$ dengan menggunakan metode Fujioka. Radang akut berdasarkan pemeriksaan laboratorium adalah bila lekosit $>11.000 /$ UL.

Pengambilan sampel jaringan (adenoid dan tonsila palatina kanan dan kiri) dilakukan di kamar operasi dengan adenotonsilektomi menggunakan bius umum. Kemudian jaringan tonsil dan adenoid dihancurkan sampai halus kemudian disentrifugasi dan disimpan pada suhu $-20{ }^{\circ} \mathrm{C}$ sampai dilakukan analisis kadar IL-6. Data kadar IL-6 tonsila palatina merupakan nilai rerata kadar IL-6 tonsila palatina kanan dan kiri. IL-6 serum didapatkan dari darah vena yang dilakukan 1 hari sebelum operasi pada saat pemasangan infus. Pengambilan darah vena sebanyak 5 $\mathrm{ml}$, kemudian serum diperoleh dengan cara sentrifugasi dan disimpan pada suhu $-20^{\circ} \mathrm{C}$ sampai dilakukan analisis kadar IL-6. Pemeriksaan kadar IL-6 jaringan dan serum dengan cara ELISA.

Data dianalisis dengan menggunakan independent t-test untuk mengetahui perbedaan kadar IL-6 serum pada penderita adenotonsilitis kronis hipertrofi dengan tanpa adenotonsilitis kronis hipertrofi dan uji korelasi dan regresi linear untuk mengetahui hubungan kadar IL-6 adenoid dan tonsila palatina dengan kadar IL- 6 serum.

\section{Hasil}

Karakteristik umum subjek penelitian kelompok kasus dan kontrol meliputi jenis kelamin dan umur disajikan pada Tabel 1 . Pasien kelompok kasus lebih banyak pada laki-laki daripada perempuan, begitu juga dengan kelompok kontrol. Rerata umur pada kelompok kasus dan kontrol tidak berbeda secara bermakna $(p>0,05)$.

Tabel 1. Karakteristik umum

\begin{tabular}{|c|c|c|c|}
\hline $\begin{array}{l}\text { Karakteristik } \\
\text { Umum }\end{array}$ & $\begin{array}{c}\text { Kasus } \\
\text { n (\%) }\end{array}$ & $\begin{array}{c}\text { Kontrol } \\
\text { n (\%) }\end{array}$ & $\mathbf{p}$ \\
\hline \multicolumn{4}{|l|}{ Jenis kelamin } \\
\hline Laki-laki & $\begin{array}{c}5 \\
(62,5 \%)\end{array}$ & $\begin{array}{c}5 \\
(62,5 \%)\end{array}$ & \\
\hline Perempuan & $\begin{array}{c}3 \\
(37.5 \%)\end{array}$ & $\begin{array}{c}3 \\
(37,5 \%)\end{array}$ & \\
\hline \multicolumn{4}{|l|}{ Kelompok umur } \\
\hline $\begin{array}{l}\text { Prasekolah (2-5 } \\
\text { tahun) }\end{array}$ & $\begin{array}{c}1 \\
(12,5 \%)\end{array}$ & $\begin{array}{c}1 \\
(12,5 \%)\end{array}$ & \\
\hline $\begin{array}{l}\text { Sekolah (6-12 } \\
\text { tahun) }\end{array}$ & $\begin{array}{c}5 \\
(62,5 \%)\end{array}$ & $\begin{array}{c}5 \\
(62,5 \%)\end{array}$ & \\
\hline $\begin{array}{l}\text { Remaja awal } \\
\text { (13-15 tahun) }\end{array}$ & $2(25 \%)$ & $2(25 \%)$ & \\
\hline $\begin{array}{l}\text { Rerata Umur } \\
\text { dalam tahun } \\
\text { (SD) }\end{array}$ & $\begin{array}{c}9,63 \\
(3,238)\end{array}$ & $\begin{array}{c}10,63 \\
(3,021)\end{array}$ & $\begin{array}{c}p= \\
0.533\end{array}$ \\
\hline
\end{tabular}

Keterangan : SD=Standar Deviasi 
Karakteristik klinis pada penelitian ini menggambarkan variabel yang diteliti pada kelompok kasus dan kontrol yang terdiri dari IMT, hemoglobin, lekosit, dan C-Reactive Protein (CRP) yang disajikan pada Tabel 2. Berdasarkan Barlow SE ${ }^{12}$ dan kurva pertumbuhan Centers for Disease Control and Prevention $(\mathrm{CDC})^{13}$, pada kelompok kasus didapatkan $5(62,5 \%)$ anak dengan IMT normal (laki-laki 3 anak, perempuan 2 anak), 2 (25\%) anak dengan obesitas (lakilaki dan perempuan masing-masing 1 anak), dan 1 (12,5\%) anak dengan berat badan kurang (laki-laki 1 anak). Sedangkan pada kelompok kontrol didapatkan $7(87,5 \%)$ anak dengan Indeks Masa Tubuh (IMT) normal (laki-laki 5 anak, perempuan 2 anak) dan 1 $(12,5 \%)$ anak dengan berat badan kurang (perempuan 1 anak). Rerata IMT pada kelompok kasus dan kontrol tidak berbeda secara bermakna dengan $p>0,05$. Rerata hemoglobin, lekosit serum, dan CRP pada kelompok kasus dan kontrol tidak berbeda secara bermakna dengan $p>0,05$ dan kadar ketiganya dalam batas normal (Tabel 2).

Peran IL-6 pada adenotonsilitis kronis hipertrofi dalam penelitian ini dikaji dengan melihat perbedaan kadar IL-6 serum pada kelompok adenotonsilitis kronis hipertrofi dengan kelompok tanpa adenotonsilitis kronis hipertrofi. Kadar IL-6 serum pada kelompok kasus lebih tinggi secara bermakna dibandingkan kelompok kontrol $(47,35 \pm 7,83$ $\mathrm{pg} / \mathrm{mL}$ vs. $37,40 \pm 9,05 \mathrm{pg} / \mathrm{mL}, \mathrm{p}<0,05)$ (Tabel 3). Hasil uji korelasi Pearson kadar IL6 adenoid dengan serum menunjukkan adanya hubungan positif yang bermakna $(p<$ 0,05 ) dengan besaran hubungan 0,881 yang menunjukkan kekuatan hubungan sangat kuat. Hasil uji korelasi kadar IL-6 tonsila palatina dengan serum menunjukkan adanya hubungan sedang $(r=0,556, p>0,05)$ namun tidak bermakna (Tabel 4).
Tabel 2. Karakteristik klinis subjek penelitian berdasarkan IMT, hemoglobin, lekosit serum, dan CRP

\begin{tabular}{|c|c|c|c|}
\hline $\begin{array}{l}\text { Karakteristik } \\
\text { Klinis }\end{array}$ & $\begin{array}{c}\text { Kasus } \\
\text { Rerata } \\
\text { (SD) }\end{array}$ & $\begin{array}{c}\text { Kontrol } \\
\text { Rerata } \\
(\mathrm{SD})\end{array}$ & p \\
\hline IMT $\left(\mathrm{kg} / \mathrm{m}^{2}\right)$ & $\begin{array}{c}18,35 \\
(5,740)\end{array}$ & $\begin{array}{c}16,28 \\
(2,235)\end{array}$ & $p=0.356$ \\
\hline $\begin{array}{l}\text { Hemoglobin } \\
(\mathrm{g} / \mathrm{dL})\end{array}$ & $\begin{array}{c}12,21 \\
(0,979)\end{array}$ & $\begin{array}{c}12,76 \\
(0,796)\end{array}$ & $p=0.238$ \\
\hline $\begin{array}{l}\text { Lekosit serum } \\
\text { (per uL) }\end{array}$ & $\begin{array}{c}8168,75 \\
(1140,3 \\
94)\end{array}$ & $\begin{array}{c}8202,5 \\
(1035,109)\end{array}$ & $p=0.951$ \\
\hline CRP (mg/dL) & $\begin{array}{c}0,11 \\
(0,091) \\
\end{array}$ & $\begin{array}{c}0,10 \\
(0,105) \\
\end{array}$ & $p=0.823$ \\
\hline
\end{tabular}

Tabel 3. Kadar IL-6 serum, adenoid, dan tonsila palatina

\begin{tabular}{|c|c|c|c|c|}
\hline & Kontrol & \multicolumn{3}{|c|}{ Kasus } \\
\hline & $\begin{array}{l}\text { Kadar } \\
\text { IL6 } \\
\text { serum } \\
\mathrm{pg} / \mathrm{ml}\end{array}$ & $\begin{array}{l}\text { Kadar } \\
\text { IL6 } \\
\text { serum } \\
\mathrm{pg} / \mathrm{ml}\end{array}$ & $\begin{array}{c}\text { Kadar } \\
\text { IL6 } \\
\text { adenoid } \\
\mathrm{pg} / \mathrm{ml}\end{array}$ & $\begin{array}{c}\text { Kadar } \\
\text { IL6 } \\
\text { tonsila } \\
\text { palatina } \\
\mathrm{pg} / \mathrm{ml}\end{array}$ \\
\hline$\overline{\mathrm{N}}$ & 8 & 8 & 8 & 8 \\
\hline Rerata & 37.4025 & 47.3531 & 49.3188 & 47.8795 \\
\hline $\mathrm{SD}$ & 9.05279 & 7.83642 & 4.10975 & 2.91708 \\
\hline
\end{tabular}

Tabel 4. Hasil uji korelasi kadar IL-6 serum dengan kadar IL-6 adenoid dan tonsila palatina

\begin{tabular}{lccc}
\hline & $\mathrm{N}$ & $\mathrm{r}$ & $\mathrm{p}$ \\
\hline IL-6 serum dengan & 8 & $0.881^{\star \star}$ & 0.004 \\
IL-6 adenoid & & & \\
IL-6 serum dengan & 8 & 0.556 & 0.197 \\
IL-6 tonsila palatina & & & \\
\hline
\end{tabular}

** : berhubungan kuat dan bermakna

\section{Pembahasan}

Pada penelitian ini didapatkan jumlah subjek penelitian pada kelompok kasus maupun kontrol menunjukkan lebih banyak laki-laki (62,5\%) daripada perempuan $(37,5 \%)$. Penelitian di India tahun 2009, tonsillitis kronis merupakan penyakit terbanyak kedua setelah otitis media yaitu sebanyak $11,76 \% .{ }^{14}$ Sedangkan di Malaysia antara Juli 2003 sampai Juni 2004, tonsillitis 
kronis menempati urutan ke-4 setelah rinitis, otitis media kronis, dan karsinoma nasofaring, dan lebih banyak pada laki-laki (52\%) daripada perempuan (48\%). ${ }^{15}$ Berdasarkan penelitian yang dilakukan oleh Gallistl et al., ${ }^{16}$ tidak terdapat perbedaan yang bermakna antara jenis kelamin dengan kadar IL-6 serum.

Adenotonsilektomi merupakan operasi yang masih sering dilakukan pada anak-anak. Di Italia antara tahun 2002-2008, tonsilektomi dan atau adenoidektomi dilakukan pada 14.770 anak antara umur 2-11 tahun, yang paling sering adalah adenotonsilektomi $64,1 \%$, diikuti adenoidektomi $31,1 \%$, dan tonsilektomi 4,8\%. ${ }^{17}$ Di Amerika, menurut National Survey of Ambulatory Surgery (NSAS), pada tahun 1996 tonsilektomi dengan atau tanpa adenoidektomi merupakan tindakan operatif kedua setelah miringotomi dengan insersi tabung, yaitu sekitar 287.000 pada anak umur kurang dari 15 tahun, adenotonsilektomi sebanyak $86,4 \%$ dan tonsilektomi sebanyak 13,6\%.18 Sedangkan di RSUD Dr. Saiful Anwar pada tahun 20102011 didapatkan 76 pasien yang dilakukan adenotonsilektomi, 40 pasien dilakukan tonsilektomi, dan 2 pasien dilakukan adenoidektomi ${ }^{19,20}$, penelitian di T urki ${ }^{21,22}$, dan Polandia ${ }^{23}$ anak dengan adenotonsilitis kronis hipertrofi yang dilakukan adenotonsilektomi lebih banyak pada laki-laki daripada perempuan.

Rerata umur pada subjek penelitian ini tidak ada perbedaan yang bermakna antara kelompok kasus $(9,63 \pm 3,24$ tahun) dan kontrol (10,62 $\pm 2,02$ tahun). Umur kelompok kasus dan kontrol berdasarkan demografi didapatkan paling banyak pada umur 6-12 tahun (62,5\% dan 75\%). Penelitian yang dilakukan oleh Odemis E et al. terhadap 103 anak dengan adenotonsilitis kronis hipertrofi didapatkan rerata umur 6,4 $\pm 0,25$ tahun. ${ }^{22}$

Pada kelompok kasus terdapat dua anak obesitas, tetapi rerata IMT pada kelompok kasus dan kontrol tidak berbeda bermakna serta masih dalam rentang berat badan normal. Terdapat penelitian yang menghubungkan antara obesitas dengan kadar IL-6 serum. Penelitian yang dilakukan Gallistl et al. menunjukkan kadar IL-6 serum pada anak obesitas secara bermakna lebih tinggi dibandingkan dengan anak dengan berat badan normal. ${ }^{16}$ IL-6 dapat dihasilkan oleh jaringan adiposa dan diperkirakan berperan pada $20 \%$ kadar di serum.

Rerata hemoglobin, lekosit serum, dan CRP pada subjek penelitian ini tidak ada perbedaan yang bermakna antara kelompok kasus dan kontrol serta kadar ketiganya dalam rentang normal. IL-6 merupakan sitokin pleiotropik yang berperan pada proses inflamasi, respons imun, reaksi fase akut, dan hematopoiesis. Pada inflamasi kronis dapat mempengaruhi hematopoiesis. Adanya inflamasi kronis memicu makrofag untuk menghasilkan IL-6. IL-6 akan menginduksi hepatosit untuk menghasilkan hepcidin. Hepcidin akan menghambat pelepasan besi oleh makrofag, menghambat penyerapan besi oleh usus halus, menyebabkan hipoferremia, sehingga terjadi anemia. ${ }^{24}$

Hasil penelitian ini membuktikan bahwa IL-6 berperan pada adenotonsilitis kronis hipertrofi. Hasil uji t menunjukkan rerata kadar IL-6 serum pada kelompok kasus lebih tinggi secara bermakna dibandingkan kelompok kontrol. Pada beberapa penelitian juga menunjukkan hasil yang sama tetapi dengan rerata kadar IL-6 serum yang berbeda. $8,25,26$ Hal ini mungkin disebabkan oleh perbedaan tempat, reagen yang digunakan, dan etnis. Berdasarkan penelitian Kiecolt-Glaser et al. perbedaan etnis menunjukkan kadar IL-6 yang berbeda pula. ${ }^{27}$ Pada etnis Afrika memiliki kadar IL-6 yang lebih tinggi daripada Amerika.

Sitokin IL-6 berperan dalam infeksi akut dan kronis. Respons inflamasi akut bertujuan untuk eradikasi mikroorganisme yang memacu respons awal. Pada beberapa keadan, eradikasi tidak efektif atau tidak 
lengkap sehingga menimbulkan fase inflamasi kronis. Inflamasi akut berhubungan dengan produksi IL-1, IL-6, dan IL-8. Sitokin ini akan merangsang hati untuk membentuk protein fase akut. Dalam klinis, pengukuran protein fase akut digunakan untuk menilai derajat inflamasi dan respons terhadap terapi. ${ }^{28}$

Peradangan kronis ditandai oleh rekrutmen monosit ke daerah peradangan yang diperankan oleh IL-6. Kompleks IL-6 dan sIL-6R $\alpha$ yang berikatan dengan gp130 melalui mekanisme trans-signaling dapat mengaktifkan sel endotel untuk menghasilkan IL-8, MCP-1, menginduksi ekspresi molekul adhesi, dan peningkatan IL-6 itu sendri. Hal inilah yang dapat meningkatkan kadar IL-6 serum. Peningkatan IL-6 yang berkepanjangan menyebabkan apoptosis netrofil dan akumulasi monosit di daerah peradangan yang merupakan petanda adanya inflamasi kronis. ${ }^{29}$ Kadar IL-6 serum meningkat pada anak Sleep Disordered Breathing (SDB), meningkat seiring dengan tingkat keparahannya, dan menurun 2 minggu dan 6 bulan setelah adenotonsilektomi. ${ }^{25}$

Penelitian tentang sitokin-sitokin yang berhubungan dengan adenotonsilitis kronis telah banyak dilakukan baik di serum maupun jaringan. Terdapat peningkatan kadar IL-6 baik di serum maupun di adenoid dan tonsila palatina pada adenotonsilitis kronis. Penelitian Kim et al. menunjukkan peningkatan kadar IL-6 pada jaringan tonsil anak dengan OSA. ${ }^{7}$ Alberti et al. menunjukkan peningkatan kadar IL-6 dan IL-8 serum pada anak dengan OSA karena adenotonsilitis kronis. ${ }^{8}$ Esteitic et al. meneliti perubahan kadar IL-6 pada anak dengan OSA karena adenotonsilitis kronis, bahwa terdapat penurunan kadar IL-6 pada jaringan tonsil hipertrofi setelah pemberian Fluticasone furoate selama 2 minggu, tetapi pengaruhnya terhadap kadar IL-6 serum tidak diteliti. ${ }^{6}$ Penelitian yang menghubungkan antara kadar IL-6 serum dengan kadar IL-6 adenoid dan tonsila palatina belum dilakukan. Pada penelitian ini menunjukkan adanya hubungan antara kadar IL-6 adenoid dengan kadar IL-6 serum pada adenotonsilitis kronis hipertrofi.

Reaksi inflamasi lokal yang persisten pada adenotonsilitis dapat menyebabkan perubahan histomorfologi dan penurunan fungsi barier. Inflamasi lokal dapat disebabkan oleh infeksi atau trauma mekanik. Bakteri dapat berkembang biak di dalam kripte sehingga menyebabkan infeksi kronis dan sumbatan pada kripte, menyebabkan stasis debris kripte dan stimuli antigen yang menetap..$^{21}$ Mekanisme trauma mekanik pada proses mendengkur juga dapat mengakibatkan keradangan kronis. ${ }^{1}$

Terdapatperbedaan patogenesis antara adenotonsillitis kronis, adenotonsillitis hipertrofi, dan adenotonsillitis kronis hipertrofi. Lopez-Gonzalez et al. meneliti perbedaan patogenesa adenotonsilitis kronis dan hipertrofi. Pada adenotonsillitis kronis disebabkan oleh respons imun terhadap bakteri, menyebabkan reaksi inflamasi, mengaktifkan endonuklease, menginduksi pemecahan DNA, sehingga terjadi apoptosis. Sedangkan adenotonsiltis hipertrofi disebabkan oleh kondisi lingkungan, nonbakteri atau alergi, sehingga menyebabkan rekrutmen basofil yang memicu reaksi radang kronis dan menghambat apoptosis sel. ${ }^{11}$ Sementara pada tonsillitis kronis dengan hipertrofi, terdapat disfungsi lokal pada limfosit. , ${ }^{23}$

Pada adenotonsilitis kronis, perubahan histomorfologi dapat terjadi pada daerah epitel kripte, ekstrafolikel, dan folikel. Perubahan epitel yaitu terutama peningkatan epitel skuamous dan penurunan jumlah epitel respirasi. Pada ekstrafolikel terjadi peningkatan jaringan fibrosis. ${ }^{1}$ Pada folikel terjadi peningkatan jumlah dan luas folikel, serta penurunan jumlah sel $B$ memori dan sel yang berproliferasi aktif. Berdasarkan penelitian yang dilakukan oleh Alatas et al., ${ }^{21}$ folikel pada tonsillitis kronis hipertrofi lebih 
besar dan lebih banyak daripada tonsillitis kronis, sehingga hipertrofi ini disebabkan oleh hiperplasi dan hipertrofi folikel limfoid. Tetapi di daerah ini juga terdapat penurunan jumlah sel B memori $\left(\mathrm{CD}^{2} \mathrm{O}^{+}\right)$dan sel yang berproliferasi aktif (sel yang mengekspresi cyclin D1). Penurunan jumlah sel yang berproliferasi aktiftidak berhubungan dengan penurunan jumlah sel B memori di daerah folikel. Karena itu adanya hiperplasi folikel mungkin terjadi karena telah terbentuk folikel baru dari sel $B$ yang berasal dari tempat lain. ${ }^{21}$ Pada peradangan kronis akan meningkatkan molekul adhesi sehingga dapat menarik sel B dari sistemik menuju adenoid yang mengalami inflamasi kronis.

Brodsky yang dikutip Gorfien et al., ${ }^{29}$ menyatakan bahwa terdapat peningkatan jumlah sel B, sel Th, dan sel T supresor pada tonsil hipertrofi bila dibandingkan dengan tonsil normal. IL-6 perperan pada pembentukan sel $T$ dan sel $B$. Pada pembentukan sel T, IL-6 dapat merubah keseimbangan Th1/Th2 menuju dominasi Th2 dengan dua mekanisme yang berbeda, yaitu mengaktifkan NFAT yang nantinya akan mengaktifkan IL-4 sehingga terbentuk Th2, dan mengupregulasi SOCS1 yang dapat menghambat sinyal IFN-r sehingga menghambatpembentukan Th1. ${ }^{30}$ IL-6 dapat mengaktifkan Th17 yang berperan sebagai mediator penyakitautoimun dan menghambat pembentukan $T$ regulator yang berfungsi sebagai penyeimbang antara Th1 dan Th2 melalui kerjasama dengan TGF- $\beta$ yang mengaktifkan STAT-3 dan ROR-r.,., 31 Dominasi sitokin Th2 menunjukkan adanya proses inflamasi kronis yang dapat memicu kerusakan jaringan. ${ }^{30}$

Pada sel B, IL-6 berperan pada proliferasi dan diferensiasi akhir sel $B$, sehingga sel $B$ memiliki kemampuan untuk membentuk immunoglobulin. Proliferasi limfosit B pada tonsillitis kronis berperan dalam mekanisme hipertrofi tonsil. Jumlah limfositB meningkatpada tonsil hipertrofi bila dibandingkan dengan tonsil normal. Gorfien et al. menyatakan bahwa terdapat peningkatan luas area germinal senter pada tonsillitis kronis hipertrofi bila dibandingkan dengan tonsila palatina yang sehat. ${ }^{29}$ Jumlah limfositB berhubungan dengan Haemophilus influenza yang merupakan bakteri dominan pada tonsillitis kronis hipertrofi. Adanya bakteri yang dominan di tonsil menyebabkan limfosit mengalami hiperplasi, refrakter atau toleran terhadap aktifasi imun oleh berbagai patogen yang menyebabkan penyakit pada tonsil. ${ }^{29}$ Kayguyus et al. menyatakan bahwa kadar lgG, IgA, dan lgM serum pada anak adenotonsilitis kronis hipertrofi lebih tinggi daripada anak sehat, kadar ketiganya menurun mendekati kadar anak sehat 1 bulan setelah tonsilektomi. ${ }^{32}$ Peningkatan immunoglobulin, sel T sitotoksik, dan sel B pada tonsillitis kronis adalah sebagai respons dari stimulus bakteri yang terus menerus. Peningkatan kadar IL-6 jaringan sebagai akibatdari stimuli antigen yang terus menerus dapat menyebabkan disfungsi limfosit sehingga menyebabkan hipertrofi, mengaktifkan sel endotel untuk menghasilkan molekul adhesi, IL-8, dan IL-6 itu sendiri sehingga kadar IL- 6 serum meningkat, serta meningkatkan migrasi sel $T$ dan sel $B$ ke daerah terjadinya peradangan.

Pada penelitian ini, hasil uji korelasi kadar IL-6 tonsila palatina dengan kadar IL-6 serum menunjukkan hubungan yang tidak bermakna, tetapi menunjukkan hubungan yang bermakna antara kadar IL-6 adenoid dengan kadar IL-6 serum. Hal ini bisa karena adanya perbedaan sitokin yang dihasilkan oleh adenoid dan tonsil palatina. Penelitian Komorowska et al. menunjukkan adanya peningkatan sekresi IL-2 dan IFN-r pada sel limfoid tonsila palatina yang distimulasi dengan phytohaemagglutinin (PHA). ${ }^{23}$ Mereka menyatakan bahwa pada tonsila palatina peran Th1 lebih dominan daripada Th2, sebaliknya adenoid. Begitu juga dengan Bernstein et al., yang dikutip oleh 
Zelazowska-Rutkowska et al. menyatakan bahwa terdapat penurunan sintesa sitokin Th1 (IL-2 dan IFN-r) pada jaringan limfoid pasien dengan hipertrofi adenoid. ${ }^{33}$ Adenoid memiliki jumlah dan luas folikel, sel B memon', dan sel yang berproliferasi aktif lebih banyak daripada tonsila palatina. ${ }^{21} \mathrm{Hal}$ ini menunjukkan bahwa adenoid lebih aktif daripada tonsila palatina. Selain itu, pada anak dengan OSA, sumbatan yang paling sering terjadi karena adenoid yang membesar.

Terdapatbeberapa keterbatasan dalam penelitian ini. Untuk menegakkan diagnosis OSA perlu dilakukan pemeriksaan polisomnografi, tetapi alat tersebut tidak tersedia di RSUD dr. Saiful Anwar Malang, sehingga penentuan OSA pada penelitian ini berdasarkan anamnesis.

Kadar IL-6 serum pada kelompok kasus lebih tinggi daripada kontrol. Pada penelitian ini terdapat subjek yang memiliki faktor alergi. Beberapa penelitian membuktikan kadar IL-6 serum dipengaruhi oleh alergi sehingga lebih tingginya kadar IL-6 serum pada kelompok kasus dapat disebabkan faktor alergi.34, 35 Adanya faktor alergi pada pemilihan kelompok kasus sulit dihindari karena terdapat penelitian yang membuktikan adanya korelasi positif antara adenotonsilitis kronis hipertrofi dengan alergi. ${ }^{36}$

Pada penelitian ini membandingkan antara kadar IL-6 serum kasus dan kontrol. Kadar IL-6 adenoid dan tonsila palatina antara kasus dan kontrol tidak dibandingkan karena tidak mungkin melakukan adenotonsilektomi pada pasien normal.

\section{Kesimpulan}

Penelitian ini menyimpulkan bahwa pada adenotonsilitis kronis hipertrofi, kadar IL-6 serum berhubungan positip dengan kadar IL-6 adenoid, namun tidak berhubungan dengan IL-6 tonsil palatina. Adanya infeksi kronis pada adenoid dan terjadinya obstruksi saluran nafas yang berkepanjangan oleh adenoid hipertrofi akan dapat meningkatkan kadar IL-6 serum .

IL-6 berperan pada adenotonsilitis kronis hipertrofi yang ditunjukkan dengan perbedaan kadar IL-6 serum pada kelompok kasus dan kontrol memungkinkan dilakukan pengendalian adenotonsilitis kronis hipertrofi dengan mengendalikan kadar IL-6 serum.

\section{Saran}

Penelitian dengan subjek penelitian yang tidak terdapat faktor alergi antara kasus dan kontrol akan memperkuat pengaruh kadar IL-6 serum terhadap adenotonsilitis kronis hipertrofi.

\section{Konflik Kepentingan}

Pada penelitian ini tidak ada konflik kepentingan.

\section{Daftar Pustaka}

1. Brodsky L, Poje C. Tonsillitis, Tonsillectomy, and Adenoidectomy. In: Bailey BJ, Johnson JT, Newlands SD, (Editors). Head \& Neck Surgery Otolaryngology. $4^{\text {th }}$ edition. Philadelphia: Lippincott Williams \& Wilkins. 2006. P. 1184-1198.

2. Von Andrian U, Mempel T. Homing and Cellular Traffic in Lymphnodes. Nature Reviews Immunology. 2003; 3:867-878.

3. Passali D, Damiani V, Passali G, Passali F, Boccazi A, Bellussi L. Structural and Immunological Characteristics of Chronically Inflamed Adenotonsillar Tissue in Childhood. American Society for Microbiology. 2004; 11(6):11541157.

4. Barnes T, Anderson M, Moots R. The Many Faces of Interleukin-6: The Role of IL-6 in Inflamation, Vasculopathy, and Fibrosis in Systemic Sclerosis. 
International Journal of Rheumatology. 2011; 1-6.

5. Kishimoto T. IL-6 : from Its Discovery to Clinical Applications. International Immunology. 2010; 22(5):347-352.

6. Esteitic R, Emani J, Sharma S, Suskind $D$, Baroody F. Effect of Fluticasone Furoate on Interleukin 6 Secretion from Adenoid Tissue in Children with Obstructive Sleep Apnea. Arch Otolaryngol Head Neck Surg. 2011; 137(6):576-582.

7. Kim J, Bhattacharjee R, DayyatE, Snow A, Gozal L, Goldman J, et al. Increased Cellular Proliferation and Inflammatory Cytokines in Tonsils Derived From Children With Obstructive Sleep Apnea. Pediatric Research. 2009; 66(4):423428.

8. Alberti A, Sarchielli P, Gallinella E, Floridi A, Mazzotta G, Gallai V. Plasma Cytokine Levels in Patients with Obstructive Sleep Apnea Syndrome: a Preliminary Study. J Sleep Res. 2003; 12:305-311.

9. Gabay C. Interleukin-6 and Chronic Inflamation. Arthritis Research \& Therapy. 2006; 8(2):1-6.

10. Fujioka $M$, Young L, Girdany B. Radiographic Evaluation of Adenoidal Size in Children: AdenoidalNasopharyngeal Ratio. AJR. 1979; 133:401-404.

11. Lopez-Gonzalez M, Diaz P, Delgado F, Lucas M. Lack of Lymphoid Cell Apoptosis in the Pathogenesis of Tonsillar Hypertrophy as Compared to Recurrent Tonsillitis. Eur J Pediatr. 1999; 158:469-473.

12. Barlow S. Expert Committee Recommendations Regarding the Prevention, Assessment, and Treatment of Child and Adolescent Overweight and Obesity: Summary Report. Pediatrics. 2007; 120:s164-s192.
13. Kuczmarski R, Ogden C, Guo S. 2000 CDC Growth Charts for the United States:Methods and Development. National Center for Health Statistics. Vital Health Stat. 2002; 11(246):31-32, 178-185.

14. Kishve S, Kumar N, Kishve P, Aarif S, Kalakoti P. Ear, Nose and Throat Disorders in Paediatric Patients at a Rural Hospital in India. Australasian Medical Journal. 2010; 3(12):786-790.

15. Sing T. Pattern of Otorhinolaryngology Head and Neck Diseases in Outpatient Clinic of a Malaysian Hospital. The Internet Journal of Head and Neck Surgery. 2007; 2(1).

16. Gallistl S, Sudi K, Aigner R, Borkenstein M. Changes in Serum Interleukin-6 Concentrations in Obese Children and Adolescents during a Weight Reduction Program. International Journal of Obesity. 2001; 25:1640-1643.

17. Motta G, Motta S, Cassano P, Conticello S, Ferretti M, Galletti B, et al. Effects of Guidelines on Adeno-tonsillar Surgery on the Clinical Behaviour of Otorhinolaryngologists in Italy. BMC Ear, Nose and Throat Disorders. 2013; 13:17.

18. Owings M, Kozak L. Ambulatory and Inpatient Procedures in the United States, 1996. National Center for Health Statistics. Vital Health Stat. 1998; 13(139):1-127.

19. SMF IImu Kesehatan THT-KL RSU Dr. Saiful Anwar. Dalam: Laporan Tahunan. Malang; 2010.

20. SMF IImu Kesehatan THT-KL RSU Dr Saiful Anwar. Dalam:Laporan Tahunan. Malang; 2011.

21. Alatas N, Baba F. Proliferating Active Cells, Lymphocyte Subsets, and Dendritic Cells in Recurrent Tonsilitis. Their Effect on Hypertrophy. Arch Otolaryngol Head Neck Surg. 2008; 134(5):477-483. 
22. Odemis E, Catal F, Karadag A, Kurtaran $\mathrm{H}$, Ark N, Mete $\mathrm{E}$. Assessment of Cardiac Function and Rheumatic Heart Disease in Children with Adenotonsillar Hypertrophy. Journal of the National Medical Association. 2006; 98(12):19731976.

23. Komorowska A, Komorowski J, Banasik $M$, Lewkowicz $P$, Tchórzewski $H$. Cytokines Locally Produced by Lymphocytes Removed from the Hypertrophic Nasopharyngeal and Palatine Tonsils. International Journal of Pediatric Otorhinolaryngology. 2005; 69(7):937-941.

24. Raj D. Role of Interleukin-6 in the Anemia of Chronic Disease. Semin Arthritis Rheum. 2009; 38:382-388.

25. Kelishadi R, Nilforoushan N, Okhovat A, Amra B, Poursafa P, Rogha M. Effects of Adenoidectomy on Markers of Endothelial Function and Inflamation in Normal-weight and Overweight Prepubescent Children with Sleep Apnea. JRMS. 2011; 16:387-394.

26. Tauman R, O'Brien L, Gozal D. Hypoxemia and Obesity Modulate Plasma C-Reactive Protein and Interleukin-6 Levels in Sleep Disordered Breathing. Sleep Breath. 2007; 11:7784.

27. Keicolt-Glaser J, Preacher $K$, MacCallum R, Atkinson C, MalarkeyW, Glaser R. Chronic Stress and Age Related Increases in the Proinflamatory Cytokine IL-6. PNAS. 2003; 100(15):9090-9095.

28. Baratawidjaya K, Rengganis I. Imunologi Dasar. Edisi ke-9. Jakarta: Balai Penerbit Fakultas Kedokteran Universitas Indonesia. 2010.

29. Gorfien J, Noble B, Hard R, Brodsky L. Quantitative Study of Germinal Center Area in Normal and Diseased Tonsils Using Image Analysis. The Annals of
Otology, Rhinology \& Laryngology. 1999; 108:398-402.

30. Diehl S, Rincon M. The Two Faces of IL6 on Th1/Th2 Differentiation. Molecular Immunology. 2002; 39:531-536.

31. Deyer J, Choy E. Therapeutic Targets in Rheumatoid Arthritis : the Interleukin-6 Receptor. Rheumatology. 2010; 49:1524.

32. Kaygusuz I, Gödekmerdan A, Karlidag T, Keles E, Yalçin S, Aral I, et al. Early Stage Impacts of Tonsillectomy on Immune Functions of Children. International Journal of Pediatric Otorhinolaryngology. 2003; 67:13111315.

33. Zelazowska-Rutkowska B, llendo E, Skotnicka B, Wysocka J, Kasprzycka E. Production of Cytokines by Mononuclear Cells of Hypertrophic Adenoids in Children with Otitis Media with Effusion. Folia Histochemica et Cytobiologica. 2012; 50(4):586-589.

34. Wong C, Ho C, Ko F, Chan C, Ho A, Hui $\mathrm{D}$, et al. Proinflammatory Cytokines (IL17, IL-6, IL-18 and IL-12) and Th Cytokines (IFN-g, IL-4, IL-10 and IL-13) in Patients with Allergic Asthma. Clin Exp Immunol. 2001; 125:177-183.

35. Canoz $M$, Erdenen $F$, Uzun $H$, Muderrisoglu C, Aydin S. The Relationship of Inflammatory Cytokines with Asthma and Obesity. Clin Invest Med. 2008; 31(6):E373-E379.

36. AkcayA, TamayZ, Dağdeviren E, Guler $\mathrm{N}$, Ones $U$, Kara $\mathrm{C}$, et al. Childhood Asthma and Its Relationship with Tonsillar Tissue. Asian Pacific Journal of Allergy and Immunology. 2006 24:129134. 